\title{
Are Immigrants at Increased Risk of Occupational Injury? A Literature Review
}

\author{
Simo Salminen
}

Finnish Institute of Occupational Health, Helsinki, Finland

\begin{abstract}
The aim of this review is to examine whether immigrant workers have a higher occupational injury rate than native employees. We collected 72 studies from around the world. A calculation based on 31 of these studies shows that the risk of occupational injury for foreign-born workers is 2.13 times higher than that of native-born workers. In seven studies immigrants actually had a lower occupational injury rate. At highest, immigrant workers had ten times the injury rate of native workers, whereas in one USA study the occupational injury rate of immigrant workers was only half of that of American-born workers. However, three studies consistently showed that immigrant workers had a higher injury rate than the original population during their first five years at the workplace, but that after five years their rate decreased to below the level of native workers. The conclusion of this study is that immigrant workers have a worse work conditions than native workers.
\end{abstract}

Keywords: Immigrant, foreign-born, native, occupational accidents, review.

\section{INTRODUCTION}

The baby boomers are reaching retirement age, which means a reduction in the workforce in the near future. Many Western countries may need to increase their productivity to ensure the well-being of the aging population. Increasing immigration is one solution to the problem. About 3.5 million people have settled down in a new country in the European Union in the last few years [1].

The aim of this review is to examine the studies on immigrant workers' occupational injuries around the world. Occupational injuries reduce the contribution of immigrant workers to the national economy.

\section{METHODS}

The studies for this literature review were chosen according to the following criteria:

1) The studies were published, most of them in peerreviewed journals. All the studies reviewed were published in English.

2) The studies included a comparison of the injury rates of immigrants and native workers.

3) The injury rates are based injuries on the job.

The studies in the summary table fulfill these criteria. In some studies the injury rate was not explicitly presented, but the injury rate was calculated by the author based on the information on the articles.

The original studies have used different methods in data collecting. Some studies are based on the national registers, some on the self-reported questionnaires and some on interviews. This variety of methods did not influence on the

*Address correspondence to this author at the Finnish Institute of Occupational Health, Helsinki, Finland; Tel: +358-30-474-2731; Fax: +35830-474-2020; E-mail: Simo.Salminen@ttl.fi relation between native and immigrant workers, because same method is used both for native and immigrant workers in the same study.

\section{FIRST STUDIES}

The first study on immigrants' occupational injuries was carried out in Singapore, when Collins showed that Chinese dockyard workers had a slightly higher injury frequency than Malay workers [2]. Non-citizens were involved in occupational fatalities three times more often than Singapore citizens [3]. A later study in Singapore showed that foreign workers had one and half times higher injury rate than local workers [4]. However, foreign workers were mostly satisfied with safety training in Singapore [5]. These studies showed that immigrant employees were more often involved in occupational injuries than native employees.

\section{EUROPE}

In Europe, immigrants' occupational injuries were first studied in England. In the Birmingham area male immigrants had higher accident rates than male English workers [6]. In a vehicle manufacturing company operating in south east England, immigrant workers were involved in occupational injuries 1.3 times more often than English workers [7]. Among patients of construction-related eye injuries in an Irish hospital, $48 \%$ were foreign-born, although their proportion among construction workers was $9 \%$ [8]. In the same line, of plastic surgery patients in Dublin, $40 \%$ of victims of occupational injuries were foreign-born workers, whereas their proportion was only $9 \%$ of the total Irish workforce [9]. These four studies show that immigrant workers have a higher injury rate than the native population in both England and Ireland.

In the Netherlands Turkish scaffolders suffered disabilities two and half times more often than Dutch scaffolders [10]. A higher injury-related mortality rate among ethnic minorities was found among men but not among women in the Netherlands [11]. Half of Dutch safety 
experts perceived a higher risk when working with foreign contractors and employees [12]. In the Netherlands, immigrant men had an increased risk of occupational injury, but for women the evidence was not clear.

In the Lazio region in Italy, immigrants were involved in occupational injuries 1.2 times more often than Italian workers [13]. Immigrant workers were also involved in injuries over three times more often than Italian workers in the Fabriano region [14]. In the factories of the area of Friuli-Venezia Giulia, immigrants were injured 1.6 times more often than Italian workers [15], and on the construction site of the high-speed railway from Torino to Novara, immigrant workers were more often involved in occupational injuries than Italian workers [16]. These four studies from Italy consistently show that immigrant workers are slightly more often involved in injuries than Italian workers.

In Spain, foreign workers were injured over four times more often than Spanish workers. Female and older foreign workers in particular had a higher injury rate than the native population [17]. Later the same authors showed that in nonfatal and fatal injuries, immigrants had over a four times higher injury rate than Spaniards [18]. The same research group again showed that foreign workers had a higher injury rate than Spanish workers [19]. One explanation for the huge difference in the injury rate between immigrant and Spanish workers is that there are two labor markets in Spain: Spanish workers pick up the better and safer jobs and immigrants are left with the more hazardous jobs [20]. Immigrants from poor African countries were more often in precarious jobs [21].

Three studies on immigrants' occupational injuries have been carried out in Scandinavia, and they all had different results to other studies in European countries. In Sweden, foreign workers had a lower accident frequency than Swedish workers [22, 23]. In Oslo, immigrant workers suffered $30 \%$ of the occupational injuries, whereas their proportion of the work force was only $12 \%$ [24]. Immigrant bus drivers in Helsinki were involved in occupational accidents less often than Finnish drivers [25]. In these studies, immigrant workers performed the same job as the native workers: they worked at an automobile plant (Sweden) or drove a bus (Finland). Thus under the same working conditions, it is possible for immigrants to work as safely as native workers.

In Germany, immigrant construction workers died accidentally less often than native workers [26]. However, male German immigrants born in the former Soviet Union (Aussedlers) had 39\% higher accident mortality than native Germans [27]. In the construction industry of Switzerland, immigrant workers had a higher injury rate than Swiss workers [28].

In conclusion, the situation of immigrant workers varied in European countries. The highest difference between immigrant and native workers was in Spain, where immigrants had even four times more occupational injuries than native workers. On the other hand, in Scandinavian countries immigrants were involved in occupational injuries less than the native population. The work life situation of immigrant workers is obviously different in these countries.

\section{ASIA AND AUSTRALIA}

In Australia, workers born overseas had slightly higher fatality rates than the native population [29]. Indian workers had a three times higher occupational injury rate than native workers in Malaysia [30]. In Taiwan, foreign workers had not higher risk of occupational injury than Taiwanese workers [31]. The studies showed that in the Far East, immigrant workers were generally at a higher risk of occupational injury.

In the Middle East, the occupational injuries of foreign workers were studied in three countries. In Bahrain, foreign workers were involved in occupational injuries over three times more often than local workers [32]. In Al-Khobar city, Saudi Arabia, the incidence of occupational injury was four times higher for foreign workers than for Saudi workers [33]. In the city of Al Ain, United Arab Emirates, foreign workers suffered $96 \%$ of occupational injuries leading to hospital treatment, whereas their proportion of the workforce was $71 \%$ [34]. There were no differences in the severity of occupational injuries between Lebanese and foreign workers [35]. The huge concentration of occupational injuries among immigrant workers was explained by the existence of two different labor markets for immigrant and native workers.

\section{NORTH AMERICA}

The first study on immigrants' occupational injury in the United States was most likely carried out by Fuentes [36], who showed that the accident rate for foreign farm workers in California was three times higher than that of the rest of the population. The California Agricultural Workers Health Survey later showed that $27 \%$ of male and $11 \%$ of female immigrant workers were involved in occupational injuries [37]. Male migrant farm workers had a similar rate of occupational injury in South Carolina compared to other hired farm workers, but they encountered personal violence more often [38]. Children of migrant farm workers had a two- to four-fold higher work-related injury rate than other students in South Texas [39]. Musculoskeletal strains/sprains, falls and contact with poison ivy were the most common injury types among migrant farm workers $[40$, 41]. They attributed the responsibility of their injuries to supervisors and bosses, although they assessed carefulness as the main injury prevention method [42]. It seems on farms, that the position of foreign workers is of a lower level than that of native farm workers.

Immigrants in the city of Alexandria, Virginia, were more often involved in occupational injuries than native workers [43]. Non-US citizens had a 1.8 times higher fatality rate than US citizens in New Mexico [44].

Almost one fifth of the US workforce is foreign-born. Hispanics are the greatest group among immigrants. Their proportion in fatalities at work has consistently increased [45]. Twenty-eight percent of Latino poultry workers in North Carolina were involved in occupational injuries [46]. When a male Latino worker is injured, his identity is dealt a double blow: he feels a failure both as a provider and as a father [47].

Several studies in the United States are based on the national statistical data sets. Based on the Bureau of Labor Statistics, foreign-born workers had a higher fatality rate 
than natives [48]. Foreign-born Hispanic workers had a 44\% higher fatality rate than the national rate [49]. They also had a $68 \%$ higher injury rate than their US-born colleagues [50]. These studies showed that foreign-born Hispanic workers were usually more often involved in occupational injuries.

Self-reported questionnaires or interviews were the second common method for examining the occupational injuries of immigrant workers. Based on the 1990-2003 National Health Interview Survey, foreign-born workers were significantly more likely to be injured while working in a paid job than US-born workers [51]. However, based on the same interview data from 1997 to 2005, foreign-born workers had a lower injury rate than US-born workers [52].

A review of three American studies shows that in general immigrants have a higher occupational injury rate than native-born American workers [53].

In addition to occupational injury, immigrant workers encountered violence at their workplace more often than the workforce as a whole. Foreign-born Asian workers had a one third lower fatality rate than the national rate, but their workplace homicide rate was almost three times higher [54]. Foreign-born nursing assistants suffered black eyes due to violence at work one and half times more often than US-born assistants [55]. Obviously clients considered immigrants especially those with a different ethnicity easy target for their aggression. Immigrant workers were at an increased risk of bullying at work [56]. The problem becomes even worse when we assume that immigrants are less likely to report violence to their supervisors.

The United States is the only advanced country that does not guarantee health care services for all of its population. This is why only $54 \%$ of injured workers met a doctor for the first day after their accident [57]. Immigrants can stay without necessary medical services, because they often work without enough sickness insurance.

In Alberta, Canada, immigrant workers were involved in occupational injuries over one and half times more often than Canadian workers [58].

\section{SUMMARY}

In Table 1, 31 studies on the occupational injuries of immigrant workers were reviewed. In the right column of the table, the rate is over 1 if the injury rate of immigrant workers was higher than that of the native population. The rate is below 1 if immigrant workers had a lower injury rate than native workers.

Table 1 indicates that 24 out of 31 studies showed that immigrant workers had a higher injury rate than native workers. Immigrants had a lower injury rate in seven studies.

The highest difference between immigrant and native workers was in the city of Al-Ain, United Arab Emirates, where immigrants had ten times more occupational injuries than native workers [34]. In Spain [17] and in Saudi Arabia [33] immigrants were involved in occupational injuries four times more often than the native population. The rate was lowest in the study [52] based on the National Health Interview Survey in the USA, where the injury rate of immigrant workers was only half that of American workers.
The gap between the highest and lowest rates was almost 18fold.

The average of the immigrant score in these 31 studies was 2.13 , showing that immigrant workers are on average over twice more often involved in occupational injuries than native workers.

\section{OTHER RESULTS OF POTENTIAL CAUSES}

This section concerned other points about the occupational safety of immigrant workers than the occupational accident rates. These factors are seriousness of injuries, dangerousness of immigrants' jobs, language barrier, overtime and unskilled jobs.

Injuries of immigrant workers were often more serious than those of the native population. This is true for example among farm workers in Greece [59]. The mortality of immigrant workers was probably underestimated in Switzerland [28].

Immigrant workers were over-represented in more dangerous jobs $[6,24,60,61]$. Foreign workers were also overrepresented in unskilled manual jobs in Switzerland [28] and in more physically demanding jobs in Canada $[62,63]$. In addition, they also knew very little about their rights at work and were thus vulnerable to employers' unfairness regarding working conditions [20]. Language and cultural differences partly explained these results.

Immigrants felt that their health and well-being was less important for their employers than production goals [20]. This is partly due to the language barrier, because many immigrants did not understand when occupational health and safety people spoke to them [64]. Immigrant workers did not receive enough safety training [60]. Safety training in English is useless for Spanish-speaking Latino workers in the United States [65]. Small construction contractors in particular should provide more safety training in Spanish [66]. Poor safety training partly explained the higher injury rate of immigrant workers.

Dutch safety experts believe that immigrant workers want to complete the job in as short a time as possible to earn as much money as possible. This is why they are ready to work as much overtime as possible [67].

Immigrant workers had a higher injury frequency than the native population during the first five years at their workplace. After five years, the frequency decreased to below that of the native population. This was true in Sweden [22,23], Australia [29] and Canada [68]. However, in the city of Alexandria, Virginia, immigrants who stayed longer in the United States were more often involved in occupational injuries [43].

\section{DISCUSSION}

This review showed that on average immigrants were involved in occupational injuries twice more often than native workers. This result is based on 31 studies from sixteen different countries. It shows that immigrant workers have a worse work life situation than the native population.

The main divider in this review is the place of birth. Immigrants are assumed to be born in countries other than the country in the study focus. However, depending on the 
Table 1. The Injury Rate of Immigrant Workers Compared to Native Population

\begin{tabular}{|c|c|c|}
\hline Source & Data & Rate \\
\hline Collins [2] & Naval shipyard in Singapore, 1955-1956 & 1.02 \\
\hline Fuentes [36] & Migrant farm workers in California, 1969 & 3.00 \\
\hline Bong, Chao \& Lee [3] & Fatal occupational accidents in Singapore, 1970-1972 & 3.11 \\
\hline Lee \& Wrench [6] & Asian factory workers in Birmingham, 1974-1975 & 1.84 \\
\hline Baker [7] & Asian car engine factory workers in south east England, 1979 & 1.28 \\
\hline Egger, Minder \& Smith [28] & Migrant construction workers in Switzerland, 1982 & 1.45 \\
\hline Corvalan, Driscoll \& Harrison [29] & Fatalities of overseas-born mine workers in Australia, 1982-1984 & 1.09 \\
\hline Döös, Laflamme \& Backström [23] & Migrant workers at Swedish automobile factory, 1986-1987 & 0.83 \\
\hline Al-Arrayed \& Hamza [32] & Migrant workers in Bahrain, 1988-1991 & 3.77 \\
\hline Wu et al. [31] & Migrant workers in Taiwan, 1991-1993 & 0.86 \\
\hline Al-Dawood [33] & Migrant workers in Al-Khobar city, Saudi Arabia, 1995 & 4.35 \\
\hline Pransky et al. [43] & Immigrant Latino workers in Alexandria, Virginia, 1997-1998 & 1.72 \\
\hline Thurston \& Verhoef [58] & Migrant workers in Alberta, Canada, 1994 & 1.70 \\
\hline Arndt et al. [26] & Foreign construction workers in Baden-Württemberg, Germany, 1986-2000 & 0.86 \\
\hline Carangan et al. [4] & Foreign workers in Singapore, 1998-1999 & 4.48 \\
\hline Elders et al. [10] & Turkish scaffolders in the Netherlands, 1981-2000 & 2.48 \\
\hline Loh \& Richardson [48] & Fatalities of foreign-born workers in USA, 2000 & 1.18 \\
\hline Farchi et al. [13] & Hospitalized foreign workers in the Lazio Region, Italy, 2000 & 1.19 \\
\hline Richardson [49] & Fatalities among foreign-born Hispanic workers, USA, 2004 & 1.44 \\
\hline Sincavage [54] & Fatalities of foreign-born Asian workers, USA, 2000-2003 & 0.69 \\
\hline Ahonen \& Benavides [17] & Non-fatal injuries of foreign workers in Spain, 2003 & 4.38 \\
\hline Sinclair et al. [51] & Nonfatal injuries of foreign-born workers, USA, 2000-2003 & 1.46 \\
\hline Colao et al. $[14]$ & Foreign workers in the Fabriano Region, Italy, 2000-2003 & 3.20 \\
\hline Mulloy et al. [44] & Non-US citizenship in New Mexico, 1998-2002 & 1.75 \\
\hline Benavides et al. [18] & Foreign workers in Spain, 2004 & 0.95 \\
\hline Patussi et al. [15] & Immigrant workers in Friuli-Venezia Giulia, Italy & 1.63 \\
\hline López-Jacob et al. [19] & Fatalities of foreign workers in Spain, 2005 & 1.34 \\
\hline Cierpich et al. [50] & Hispanic workers in the US, 2003-2006 & 1.68 \\
\hline Zhang et al. [52] & National Health Interview Survey, USA, 1997-2005 & 0.56 \\
\hline Salminen et al. [25] & Bus drivers in Helsinki, Finland, 2005-2006 & 0.68 \\
\hline Barss et al. [34] & Hospitalization in the city of Al-Ain, UAE, 2003-2005 & 10.04 \\
\hline
\end{tabular}

country children of immigrants are sometimes counted as immigrants and sometimes as natives. In the same way, it is not necessarily true that all people born in the country are counted as native population. An additional problem is those people with double citizenships, whose parents are born in different countries. Despite this, however, the place of birth is the best criteria for distinguishing immigrant and native workers.

I assume that the most of immigrants in these studies are legal ones. Illegal immigrants perhaps don't want to answer questionnaires or their injuries are not included in the official statistics. Studies based on the hospital data could include also illegal immigrants, because in the case of serious injury one has to find medical help.

Most studies are based on self-reporting of occupational injuries. Cultural factors and language skills may determine the reporting of injuries. For example, immigrant workers from Southeastern Asia in Lowell, Massachusetts [69], and immigrants from many different countries in Montreal [64] did not report all their injuries. Latino workers in the United States fear employer punishment and thus did not report workplace incidents or injuries [65]. Another reason is their illiteracy: they are more willing to participate in a telephone interview about safety climate in their company rather than 
answer questionnaires [70]. In conclusion, immigrant workers generally underreport their occupational injuries.

Some studies from Sweden and Australia showed that during first five years immigrants had a higher injury rates than native workers. Of course first days and weeks on the new job are the most dangerous [71]: that is true both for immigrant and native workers. The injury rate of immigrants decreased slower with the experience than that of native workers [23].

Education is one possible solution for the unfavorable conditions of immigrant workers, because part of them is illiteracy workers. However, education protects foreign-born Asians less than native-born Americans against disability, because Asian immigrants have more language difficulties [72]. Migration from Asia to the United States is good for the immigrants' mental health [73]. Thus the means for achieving equality for immigrant workers must be found in work life.

\section{ACKNOWLEDGEMENT}

None declared.

\section{CONFLICT OF INTEREST}

None declared.

\section{REFERENCES}

[1] Eurostat. Health and safety at work in Europe (1999-2007). Luxembourg: Publication Office of the European Union 2010.

[2] Collins CP. Accidents in a naval dockyard. Br J Ind Med 1959; 16 : 208-15.

[3] Bong A, Chao TC, Lee J. Risks of death from industrial accidents of foreign workers in Singapore. Ann Acad Med 1976; 5(2): 13842.

[4] Carangan M, Tham KY, Seow E. Work-related injury sustained by foreign workers in Singapore. Ann Acad Med Singapore 2004; 33(2): 209-13.

[5] Ong VYK, Habibah AK, Lee FCY. Safety among foreign workers and impact on emergency medicine services in Singapore. Singapore Med J 2006; 47(2): 121-8.

[6] Lee G, Wrench J. "Accident-prone immigrants": an assumption challenged. Sociology 1980; 14: 551-66.

[7] Baker CC. Ethnic differences in accident rates at work. Br J Ind Med 1987; 44: 206-11.

[8] Connell PP, Saddak T, Harrison I, et al. Construction-related eye injuries in Irish nationals and non-nationals: attitudes and strategies for prevention. Ir J Med Sci 2007; 176: 11-4.

[9] Davidson CC, Orr DJ. Occupational injuries in foreign-national workers presenting to St. James's Plastic Surgery Service. Irish Med J 2009; 102(4): 1-3.

[10] Elders LAM, Burdorf A, Öry FG. Ethnic differences in disability risk between Dutch and Turkish scaffolders. J Occup Health 2004; 46: 391-7.

[11] Stirbu I, Kunst AE, Bos V, van Beeck EF. Injury mortality among ethnic minority groups in the Netherlands. J Epidemiol Community Health 2006; 60: 249-55.

[12] Schubert U, Dijkstra JJ. Working safety with foreign contractors and personnel. Saf Sc 2009; 47(6): 786-93.

[13] Farchi S, Rossi PG, Chini F, et al. I traumi negli immigrati da paesi non industrializzati: analisi degli accessi in pronto soccorso nel Lazio Nell'anno 2000. Ann Ig 2005; 17(4): 335-42.

[14] Colao AM, Pisciottano V, Giampaoletti C, Cenci G. Il fenomeno infortunistico nei lavoratori extracomunitari della zona territoriale n. 6 Fabriano. Med Lav 2006; 97(6): 787-98.

[15] Patussi V, Barbina P, Barbone F, et al. Comparison of the incidence rate of occupational injuries among permanent, temporary and immigrant workers in Friuli-Venizia Giulia. Epidemiol Prev 2008; 32(1): 35-8.

[16] Bena A, Berchialla P, Debernardi ML, Pasqualini O, Farina E, Costa G. Impact of organization on occupational injury risk: evidence from high-speed railway construction. Am J Ind Med 2011; 54(6): 428-37.

[17] Ahonen EQ, Benavides FG. Risk of fatal and non-fatal occupational injury in foreign workers in Spain. J Epidemiol Community Health 2006; 60(5): 424-6.

[18] Benavides FG, Ahonen EQ, Bosch C. Riesgo de lesión por accidente laboral en trabajadores extranjeros (España, 2003 y 2004). Gac Sanit 2008; 22(1): 44-7.

[19] López-Jacob MJ, Ahonen E, García AM, Gil Á, Benavides FG. Comparación de las lesiones for accidente de trabajo en trabajadores extranjeros y Espanoles por actividad económica y comunidad autónoma (Espana, 2005). Rev Esp Salud Pùblica 2008; 82(2): 179-87.

[20] López-Jacob MJ, Safont EC, García AM, et al. Participation and influence of migrant workers on working conditions: A qualitative approach. New Solutions 2010; 20(2): 225-38.

[21] Malmusi D, Borrell C, Benach J. Migration-related health inequalities: Showing the complex interactions between gender, social class and place of origin. Soc Sc Med 2010; 71(9): 1610-9.

[22] Döös M, Laflamme L, Backström T. Invandrare och arbetsolycksfall. En jämförande studie av olycksfall bland utländska och svenska medborgare. Arbete och Hälsa 1993:33. Solna: Arbetsmiljöinstitutet 1993.

[23] Döös M, Laflamme L, Backström T. Immigrants and occupational accidents: A comparative study of the frequency and types of accidents encountered by foreign and Swedish citizens at an engineering plant in Sweden. Saf Sci 1994; 18(1): 15-32.

[24] Gravseth HM, Lund J, Wergeland E. Arbeidsskader behandlet ved Legevakten i Oslo og Ambulansetjenesten. Tidsskr Nor Laegeforen 2003; 123(15): 2060-4.

[25] Salminen S, Vartia M, Giorgiani T. Occupational injuries of immigrant and Finnish bus drivers. J Saf Res 2009; 40(3): 203-5.

[26] Arndt V, Rothenbacher D, Daniel U, Zschenderlein B, Schuberth S, Brenner H. All-cause and cause specific mortality in a cohort of 20 000 construction workers: results from a 10 year follow up. Occup Environ Med 2004; 61: 419-25.

[27] Kyobutungi C, Ronellenfitsch U, Razum O, Becher H. Mortality from external causes among ethnic German immigrants from former Soviet Union countries, in Germany. Eur J Public Health 2006; 16(4): 376-82

[28] Egger M, Minder CE, Smith GD. Health inequalities and migrant workers in Switzerland. Lancet 1990; 336(8718): 816.

[29] Corvalan CF, Driscoll TR, Harrison JE. Role of migrant factors in work-related fatalities in Australia. Scand J Work Environ Health 1994; 20(5): 364-70.

[30] Abas AL, Said ARM, Mohammed MAA, Sathiakumar N. Nonfatal occupational injuries among non-governmental employees in Malaysia. Int J Occup Environ Health 2011; 17: 38-48.

[31] Wu T-N, Liou S-H, Hsu C-C, et al. Epidemiologic study of occupational injuries among foreign and native workers in Taiwan. Am J Ind Med 1997; 31: 623-30.

[32] Al-Arrayed A, Hamza A. Occupational injuries in Bahrain. Occup Med 1995; 45(5): 231-3.

[33] Al-Dawood K. Non-fatal occupational injuries requiring admission to hospitals in Al-Khobar City, Saudi Arabia: Prospective cohort study. Croat Med J 2000; 41(3): 323-6.

[34] Barss P, Addley K, Grivna M, Stanculescu C, Abu-Zidan F. Occupational injury in the United Arab Emirates: epidemiology and prevention. Occup Med 2009;59(7): 493-8.

[35] Nuwayhid I, Fayad R, Tamim H, Kassak K, Khogali M. Workrelated injuries in Lebanon: Does nationality make a difference? Am J Ind Med 2003; 44:172-81.

[36] Fuentes JA. The need for effective and comprehensive planning for migrant workers. Am J Public Health 1974; 64(1): 2-10.

[37] Villarejo D, McCurdy SA, Bade B, Samuels S, Lighthall D, Williams D. The health of California's immigrant hired farmworkers. Am J Ind Med 2010; 53: 387-97.

[38] McDermott S, Lee CV. Injury among male migrant farm workers in South Carolina. J Community Health 1990; 15(5): 297-305.

[39] Cooper SP, Weller NF, Fox EE, Cooper SR. Comparative description of migrant farmworkers versus other students attending rural South Texas schools: Substance use, work, and injuries. J Rural Health 2005; 21(4): 361-6.

[40] Earle-Richardson G, Jenkins PL, Slingerland DT, Mason C, Miles M, May JJ. Occupational injury and illness among migrant and seasonal farmworkers in New York State and Pennsylvania, 1997- 
1999: Pilot study of a new surveillance method. Am J Ind Med 2003; 44: 37-45.

[41] Brower MA, Earle-Richardson GB, May JJ, Jenkins PL. Occupational injury and treatment patterns of migrant and seasonal farmworkers. J Agromed 2009; 14: 172-8.

[42] Stallones L, Vela Acosta MS, Sample P, Bigelow P, Rosales M. Perspectives on safety and health among migrant and seasonal farmworkers in the United States and Mexico: A qualitative field study. J Rural Health 2009; 25(2): 219-25.

[43] Pransky G, Moshenberg D, Benjamin K, Portillo S, Thackrey JL, Hill-Fotouhi C. Occupational risks and injuries in non-agricultural immigrant Latino workers. Am J Ind Med 2002; 42: 117-23.

[44] Mulloy KB, Moraga-McHaley S, Crandall C, Kesler DO. Occupational injury mortality: New Mexico 1998-2002. Am J Ind Med 2007; 50(12): 910-20.

[45] Menendez CKC, Havea SA. Temporal patterns in work-related fatalities among foreign-born workers in the US, 1992-2007. J Immigrant Minority Health 2011; 13(5): 954-62.

[46] Quandt SA, Grzywacz JG, Marin A, et al. Illnesses and injuries reported by Latino poultry workers in Western North Carolina. Am J Ind Med 2006; 49: 343-51.

[47] Walter N, Bourgois P, Loinaz HM. Masculinity and undocumented labor migration: injured Latino day laborers in San Francisco. Soc Sci Med 2004; 59: 1159-68.

[48] Loh K, Richardson S. Foreign-born workers: trends in fatal occupational injuries, 1996-2001. Mon Labor Rev 2004; 127(6): 42-53.

[49] Richardson S. Fatal work injuries among foreign-born Hispanic workers. Mon Labor Rev 2005; 128(10): 63-7.

[50] Cierpich H, Styles L, Harrison R, et al. Work-related injury deaths among Hispanics - United States, 1992-2006. MMWR Morbid Mortal Wkly Rep 2008; 57(22): 597-600.

[51] Sinclair SA, Smith GA, Xiang H. A comparison of nonfatal unintentional injuries in the United States among U.S.-born and foreign-born persons. J Community Health 2006; 31(4): 303-25.

[52] Zhang X, Yu S, Wheeler K, Kelleher K, Stallones L, Xiang H. Work-related non-fatal injuries among foreign-born and US-born workers: Findings from the U.S. National Health Interview Survey, 1997-2005. Am J Ind Med 2009; 52(1): 25-36.

[53] Argeseanu Cunningham S, Ruben JD, Venkat Narayan KM. Health of foreign-born people in the United States: A review. Health Place 2008; 14(4): 623-35.

[54] Sincavage JR. Fatal occupational injuries among Asian workers. Mon Labor Rev 2005; 128(10): 49-55.

[55] Tak SW, Alterman T, Baron S, Calvert GM. Racial and ethnic disparities in work-related injuries and socio-economic resources among nursing assistants employed in US nursing homes. Am J Ind Med 2010; 53: 951-9.

[56] Hogh A, Gomes Carneiro I, Giver H, Rugulies R. Are immigrants in the nursing industry at increased risk of bullying at work? A oneyear follow-up study. Scand J Psychol 2011; 52(1): 49-56.
[57] Dembe A. Social inequalities in occupational health and health care for work-related injuries and illnesses. Int J Law Psych 1999; 22(56): $567-79$

[58] Thurston W, Verhoef M. Occupational injury among immigrants. J Inter Migr Integr 2003; 4(1): 105-23.

[59] Alexe DM, Petridou E, Dessypris N, Skenderis N, Trichopoulos D. Characteristics of farm injuries in Greece. J Agric Saf Health 2003; 9(3): 233-40.

[60] Bollini P, Siem H. No real progress towards equity: Health of migrants and ethnic minorities on the eve of the year 2000. Soc Sc Med 1995; 41(6): 819-28.

[61] Forst L, Avila S, Anozie S, Rubin R. Traumatic occupational injuries in Hispanic and foreign born workers. Am J Ind Med 2010; 53(4): 344-51.

[62] Smith PM, Chen C, Mustard C. Differential risk of employment in more physically demanding jobs among a recent cohort of immigrants to Canada. Injury Prev 2009; 15(4): 252-8.

[63] Smith PM, Mustard CA. The unequal distribution of occupational health and safety risks among immigrants to Canada compared to Canadian-born labour market participants: 1993-2005. Saf Sci 2010; 48(10): 1296-303.

[64] Premji S, Messing K, Lippel K. Broken English, broken bones? Mechanisms linking language proficiency and occupational health in a Montreal garment factory. Int J Health Serv 2008; 38(1): 1-19.

[65] Vázquez RF, Stalnaker CK. Latino workers in the construction industry. Prof Saf 2004; 49(6): 24-8.

[66] Menzel NN, Gutierrez AP. Latino worker perceptions of construction risks. Am J Ind Med 2010; 53(2): 179-87.

[67] Schubert U, Dijkstra JJ. Working safety with foreign contractors and personnel. Saf Sci 2009; 47(6): 786-93.

[68] Smith PM, Mustard CA. Comparing the risk of work-related injuries between immigrant and Canadian-born labour market participants. Occup Environ Med 2009; 66: 361-7.

[69] Azaroff LS, Levenstein C, Wegman DH. Occupational health of Southeast Asian immigrants in a US city: A comparison of data sources. Am J Public Health 2003; 93(4): 593-8.

[70] Jorgensen E, Sokas RK, Nickels L, Gao W, Gittleman JL. An English/Spanish safety climate scale for construction workers. Am J Ind Med 2007; 50: 438-42.

[71] Larsson T. Risk and the inexperienced worker: attitudes of a social anthropologist. J Occup Health Safety Aust NZ 1988; 4: 35-40.

[72] Lee M-A. Disparity in disability between native-born non-Hispanic white and foreign-born Asian older adults in the United States: Effects of educational attainment and age at immigration. Soc Sci Med 2011; 72: 1249-57.

[73] Gong F, Xu J, Fujishiro K, Takeuchi DT. A life course perspective on migration and mental health among Asian immigrants: The role of human agency. Soc Sci Med 2011; 73: 1618-26.

This is an open access article licensed under the terms of the Creative Commons Attribution Non-Commercial License (http: //creativecommons.org/licenses/ by-nc/3.0/) which permits unrestricted, non-commercial use, distribution and reproduction in any medium, provided the work is properly cited. 